\title{
COMMENTARY
}

\section{Hypoglycemia in critically ill adults - association yes, causation not proven}

\author{
Simon Finfer ${ }^{* 1-3}$
}

See related research by Krinsley et al., http://ccforum.com/content/15/4/R173

\begin{abstract}
Hypoglycemia is consistently associated with an increased risk of death in hospital patients in general, patients treated in intensive care units, and type II diabetes patients recruited to large randomized controlled trials. In 1965, Sir Austin Bradford Hill elucidated nine characteristics that help establish a causal relationship between exposure to a potentially harmful substance or event (in this context, hypoglycemia) and disease onset or death; hypoglycemia exhibits some of those characteristics but others remain to be explored. While we await data that address the outstanding issues, common sense dictates that clinicians avoid causing hypoglycemia whenever possible.
\end{abstract}

In a previous issue of Critical Care, Krinsley and colleagues [1] report findings consistent with those of other investigators, namely that moderate hypoglycemia occurring in patients treated in intensive care units (ICUs) is associated with an increased risk of death. That hypoglycemia is associated with an increased risk of death is not necessarily news; it is a consistent finding in different populations, including patients treated in ICUs $[2,3]$ and type II diabetes patients recruited to large randomized controlled trials $[4,5]$. The authors' report replicates those research findings but also highlights the complexity of unraveling association from causation and the importance of using the correct methodology when analyzing such data.

Krinsley and colleagues report on a cohort of patients drawn from a hospital in the US, patients from three hospitals in The Netherlands, and patients recruited to

*Correspondence: sfinfer@georgeinstitute.org.au

'Intensive Care Unit, Royal North Shore Hospital, Pacific Highway, St Leonards, NSW 2065, Australia

Full list of author information is available at the end of the article the Glucontrol Study [6]. Although it is clear that hypoglycemia is associated with an increased risk of death, a causal relationship has not been established. As with any observed physiological abnormality, the occurrence of hypoglycemia may be a marker of disease severity and so merely indicate that a patient is sick and at increased risk of dying or it may be truly harmful and act independently to increase the risk of death. Is it possible to tease out the role of hypoglycemia in the mortality of critically ill patients, and does the report by Krinsley and colleagues help us to do so?

In 1965, Sir Austin Bradford Hill [7] elucidated nine characteristics that help establish a causal relationship between exposure to a potentially harmful substance or event and disease onset or death: (a) the strength of the association, (b) its consistency, (c) its specificity (is it associated with death from a specific cause?), (d) its temporal relationship, (e) its biological gradient (is there a dose-response relationship?), (f) its plausibility, (g) coherence (the hypothesis does not conflict with the known natural history of the disease), (h) experiment (if other factors are kept equal, does preventing exposure reduce the risk of death?), and (i) analogy (does manipulating factors that are similarly associated with an increased risk of death improve outcome?). Applying Hill's criteria we can conclude that the association between hypoglycemia and death, though not overly strong, is consistent, and there is evidence of a doseresponse relationship [2]. It is plausible given that hypoglycemia has many known adverse physiological effects [8-10], and the hypothesis does not conflict with our current view of the natural history of critical illness. Where we run into trouble is in the areas of the temporal nature of the relationship, its specificity, and analogy.

To establish the temporal relationship, we must demonstrate that hypoglycemia occurring in patients who were not already dying increases the subsequent risk of death; this is very difficult to do. For example, it is clear that hypoglycemia occurs in patients with acute hepatic necrosis and that hypoglycemia is a marker of a severe disease that is killing a patient but hypoglycemia is not the cause of death. Such gross examples are relatively 
easy to identify, and such patients can be removed from analysis; what we do not know is whether more subtle examples of the same phenomenon are contaminating the remaining data.

Specificity refers to an association that is present only, or at least more strongly, for death from a certain specific cause. For example, cigarette smoking is more strongly associated with death from lung cancer than death from other causes. Few ICU databases or clinical trials record cause-specific mortality and so the specificity of the relationship is currently unclear. The NICE-SUGAR (Normoglycaemia in Intensive Care Evaluation and Survival Using Glucose Algorithm Regulation) investigators did report cause-specific mortality [11]; it is possible that a careful analysis of that data could prove useful. If we were able to exclude patients whose hypoglycemia was indicative of their dying from another cause and if we found a strong association with a specific cause of death, we would still have the problem of knowing whether hypoglycemia is harmful per se or indicative of some other glucose control feature that is harmful. The most likely candidate might be glucose variability, which is also independently associated with an increased risk of death $[12,13]$.

Analogy refers to the idea that a causal relationship is more likely if similar associations have been clearly established as causal. Candidates in this context include hyperglycemia (which can be expressed in a number of ways but, to date, has been expressed mostly as mean blood glucose) and blood glucose variability given that both are strongly associated with an increased risk of death. To date, trials of lowering mean blood glucose have not improved outcome [14] and a causal relationship is not established for glucose variability. A further complication is the possibility that hypoglycemia itself may not be harmful but that the harm comes instead from rapid correction of hypoglycemia leading to rebound hyperglycemia [15].

So where does that leave us? It is clear that even moderate hypoglycemia is associated with an increased risk of death, but a causal relationship is not, and perhaps cannot be, firmly established. While the association with an increased risk of death is clear, it is entirely possible that hypoglycemia has important but less apparent longterm effects in survivors; an obvious concern would be neurological injury that might be apparent only with careful neuropsychiatric testing.

Future research can contribute to our knowledge by reporting cause-specific mortality, by analyzing timedependent variables up to and following episodes of hypoglycemia to clearly establish the temporal relationship, and by determining whether the impact of hypoglycemia is independent of other indices of glucose control. In the meantime, it is hard to argue with the commonsense conclusion that clinicians should seek to avoid hypoglycemia, defined as a blood glucose concentration of $3.9 \mathrm{mmol} / \mathrm{L}(70 \mathrm{mg} / \mathrm{dL})$ or less [16], wherever possible in critically ill patients.

\section{Abbreviation \\ ICU, intensive care unit.}

\section{Competing interests}

The author declares that he has no competing interests.

\section{Author details}

'Intensive Care Unit, Royal North Shore Hospital, Pacific Highway, St Leonards, NSW 2065, Australia. ${ }^{2}$ Critical Care and Trauma, The George Institute for Global Health Sydney, Royal North Shore Hospital, Pacific Highway, St Leonards, NSW 2065, Australia. ${ }^{3}$ Sydney Medical School, University of Sydney, Royal North Shore Hospital, Pacific Highway, St Leonards, NSW 2065, Australia.

\section{Published: 30 November 2011}

\section{References}

1. Krinsley J, Schultz MJ, Spronk PE, Harmsen RE, van Braam Houckgeest F, van der Sluijs JP, Melot C, Preiser JC: Mild hypoglycemia is independently associated with increased mortality in the critically ill. Crit Care 2011, 15:R173.

2. Egi M, Bellomo R, Stachowski E, French CJ, Hart GK, Taori G, Hegarty C, Bailey M: Hypoglycemia and outcome in critically ill patients. Mayo Clin Proc 2010, 85:217-224.

3. Hermanides J, Bosman RJ, Vriesendorp TM, Dotsch R, Rosendaal FR, Zandstra DF, Hoekstra JB, Devries JH: Hypoglycemia is associated with intensive care unit mortality. Crit Care Med 2010, 38:1430-1434.

4. Zoungas S, Patel A, Chalmers J, de Galan BE, Li Q, Billot L, Woodward M, Ninomiya T, Neal B, MacMahon S, Grobbee DE, Kengne AP, Marre M, Heller S; ADVANCE Collaborative Group: Severe hypoglycemia and risks of vascular events and death. N Engl J Med 2010, 363:1410-1418.

5. Bonds DE, Miller ME, Bergenstal RM, Buse JB, Byington RP, Cutler JA, Dudl RJ, Ismail-Beigi F, Kimel AR, Hoogwerf B, Horowitz KR, Savage PJ, Seaquist ER Simmons DL, Sivitz WI, Speril-Hillen JM, Sweeney ME: The association between symptomatic, severe hypoglycaemia and mortality in type 2 diabetes: retrospective epidemiological analysis of the ACCORD study. BMJ 2010, 340:b4909.

6. Preiser JC, Devos P, Ruiz-Santana S, Mélot C, Annane D, Groeneveld J, lapichino G, Leverve X, Nitenberg G, Singer P, Wernerman J, Joannidis M, Stecher A, Chioléro R: A prospective randomised multi-centre controlled trial on tight glucose control by intensive insulin therapy in adult intensive care units: the Glucontrol study. Intensive Care Med 2009, 35:1738-1748.

7. Hill AB: The environment and disease: association or causation? Proc R SoC Med 1965, 58:295-300.

8. Adler GK, Bonyhay I, Failing H, Waring E, Dotson S, Freeman R: Antecedent hypoglycemia impairs autonomic cardiovascular function: implications for rigorous glycemic control. Diabetes 2009, 58:360

9. Wright RJ, Frier BM: Vascular disease and diabetes: is hypoglycaemia an aggravating factor? Diabetes Metab Res Rev 2008, 24:353-363.

10. Herlein JA, Morgan DA, Phillips BG, Haynes WG, Sivitz WI, Herlein JA, Morgan DA, Phillips BG, Haynes WG, Sivitz WI: Antecedent hypoglycemia, catecholamine depletion, and subsequent sympathetic neural responses. Endocrinology 2006, 147:2781-2788.

11. NICE-SUGAR Study Investigators, Finfer $S$, Chittock DR, Su SY, Blair D, Foster D, Dhingra V, Bellomo R, Cook D, Dodek P, Henderson WR, Hébert PC, Heritier S, Heyland DK, McArthur C, McDonald E, Mitchell I, Myburgh JA, Norton R, Potter J, Robinson BG, Ronco JJ: Intensive versus conventional glucose control in critically ill patients. N Engl J Med 2009, 360:1283-1297.

12. Egi M, Bellomo R, Stachowski E, French CJ, Hart G: Variability of blood glucose concentration and short-term mortality in critically ill patients. Anesthesiology 2006, 105:244-252.

13. Hermanides J, Vriesendorp TM, Bosman RJ, Zandstra DF, Hoekstra JB, Devries $\mathrm{JH}$ : Glucose variability is associated with intensive care unit mortality. Crit Care Med 2010, 38:838-842

14. Kansagara D, Fu R, Freeman M, Wolf F, Helfand M: Intensive insulin therapy in 
Finfer Critical Care 2011, 15:1012

Page 3 of 3

http://ccforum.com/content/15/6/1012

hospitalized patients: a systematic review. Ann Intern Med 2011, 154:268-282.

15. Suh SW, Gum ET, Hamby AM, Chan PH, Swanson RA: Hypoglycemic neuronal death is triggered by glucose reperfusion and activation of neuronal NADPH oxidase. J Clin Invest 2007, 117:910-918.

16. Workgroup on Hypoglycemia: The American Diabetes Association: Defining and reporting hypoglycemia in diabetes: a report from the
American Diabetes Association Workgroup on Hypoglycemia. Diabetes Care 2005, 28:1245-1249.

doi:10.1186/cc10427

Cite this article as: Finfer S: Hypoglycemia in critically ill adults - association

yes, causation not proven. Critical Care 2011, 15:1012. 